observations on the changes of levels of rivers, as well as for meteorological observations and for weather-warnings.

THE official Report on the Forests in the South and West of the Island of Cyprus, by Mr. A. E. Wild, of the Indian Forest Department, goes far to explain the unhealthy climatic conditions now existing in the island, and of which so much was recently said. In the region named the forests are now mostly confined to the chain of hills running east and west, and even there the more dense and better growth is confined to the more inaccessible spots of the higher ranges. Round the villages and in suitable localities for transport the forest is already so thinned as to be unworthy of the name. This unfortunate state of things, which has had a serious effect on the climate, has been brought about by the most reckless improvidence in the felling of trees, aided by fires and the ruinous mode of extracting resin. Mr. Wild appears to be of opinion that by a careful system of forest preservation, which need not involve us in a large expenditure of money, the damage caused under the Lusignan and Turkish rule, may be to a material extent repaired in the course of fifty or sixty years.

M. E. F. BERLIOUX, Professor of Geography at Lyons, has just issued a second edition, reviser, and enlarged, of his brochure, entitled "Les Anciennes Explorations et les Futures Decouvertes de l'Afrique Centrale," which is illustrated with a curious map of the northern portion of the continent.

A PARTY of forty-seven persons, amongst whom there are twelve married couples, and fourteen children, sailed last week from Bergen (Norway), with the intention of colonising the Aldabra Islands in the Indian Ocean (in about $9^{\circ}$ lat. S. and $46^{\circ}$ long. E.). The idea resulting in this undertaking was first conceived by two Norwegians, who had repeatedly visited Madagascar, where they had learnt that the Aldabra Islands are uninhabited at present, and excellently adapted for colonisation.

MUCH attention is just now being attracted in Queensland to the proposed scheme for a Transcontinental railway to Port Darwin on the northern coast, of the suggested route for which a flying survey has recently been made by Mr. Faveuc and a party who started from Blackall, in Queensland. The present idea is to commence the line at Roma on the existing system, whence it would be taken by way of Blackall to the South Australian frontier, a distance of 750 miles. From that point it would still follow a north-westerly direction to Port Darwin.

A MEMBER of the Japanese mission now at the capital of Corea writes to the Osaka Nippo that the new ports, which it is proposed to open in that country, are Jin-sen, in Kei-ki-dō, and Gen-san, in Kan-kiyo-dō, the former of which is only eight $r i$ distant from the capital. A Japanese surveying officer has also been engaged in making investigations at the port of Dai-on, in Kei-ki-dō, about eighteen rifrom the capital, along the road to which there are many royal tombs. Partly on this account, and also because the road is considered a very important one, the Coreans for some time obstinately refused to permit the surveying officer to travel over it; eventually, however, they gave way. Great benefit, it is thought, would accrue to commerce if this overland route were opened. The Corean capital numbers among its residents many nobles and wealthy men, and several of the latter, who hold progressive ideas, are said to have ordered European articles at the open port of Fusan in the south. When the port of Jin-sen comes to be opened, it is believed that foreign merchandise will be in great demand.

OFFICIAL statistics respecting the population of Netherlands India at the end of 1876 have lately been issued, from which it appears that exclusive of the army, there were then in Java and Madura I8,515,4I4 people, being an increase of about 170,000 over the previous year. The natives figure for $18,278,998$, of whom $8,921,348$ were males, while the remainder is made up of Europeans, Chinese, Arabs, and other foreign Orientals, the Celestials being, of course, in a large majority. This remark also applies to the other possessions in Netherlands India, including Sumatra, Celebes, \&c. Owing to the incompleteness of the returns of natives in these islands, no estimate of their total population can be arrived at.

\section{WILLIAM WILSON SAUNDERS}

WILLIAM WILSON SAUNDERS, F.R.S., F.L.S. \&c., who, as we stated last week, died on September I3, was born June 4, I809, the son of the Rev. James Saunders, Vicar of Kirtlington. He was educated at Addiscombe, and went to India as an engineer officer in the Hon. East India Company's service. While there he published his first scientific paper, in Gleanings in Science "Cn Hydraulic Cements," in I831, and also devoted a great part of his leisure to the study of plants and insects, and made collections, which he brought back with him in 1832 . Having left the service, he settled at Wandsworth, and shortly after joined his father-in-law in business at Lloyds, still continuing his natural history studies. He was one of the original members of the Entomological Society, and read his first paper, "On the Habits of some Indian Insects," in April, I834. "This was followed by many others, mostly of a descriptive nature. He was President of the Society in $184 \mathrm{I}, \mathrm{I} 856$, and 1857 , and many times served as vice-president. He was also elected a Fellow of the Linnean Society in 1833 , and was vice-president from 1856 to 1874 , and treasurer from 1861 to 1873 . He became a Fellow of the Royal Society in 1853, and was also a Fellow of the Zoological Society and Royal Horticultural Society, and on the Council of the latter he took an active part. His natural history collections gradually increased in extent from the time of his return from India, and he devoted himself principally while at Wandsworth to horticulture and entomology and to the formation of an extensive herbarium and collection of woods, with notes of the density and weight per cubic foot of each, which latter was exhibited at the great Exhibition of $185 \mathrm{I}$. The Report of the Juries for the Exhibition gives a classified catalogue of them, with remarks as to their uses, \&c.

In 1857 be went to reside at Hallfield, Reigate, and removed there his various collections, largely extending them, and adding collections of birds, shells, vegetable products, \&c. His attention, however, was always mainly given to horticulture and entomology, and especially to the study and cultivation of the aloes, Crassulaceæ, Cacti, and otber succulent plants which could not be duly studied in an herbarium, and to the smaller and more obscure species of orchids; and it was to bring these interesting and curious plants more prominently before the botanical world that he resolved on the publication of the "Refugium Botanicum," the first number of which appeared in April, I868. In this work he had the valuable assistance of Prof. H. G. Reichenbach for the descriptions of the orchids, and of Mr. J. G. Baker, of Kew, for the other families, the plates being chiefly from the drawings of the well-known botanical artist Mr. Fitch, although some were from drawings of his own. The Fungi also attracted a good deal of his attention, and he made a series of very accurate drawings of all he was able to obtain, some of which have been reproduced in the "Mycological Illustrations," edited by him with the assistance of Mr. Worthington G. Smyth and Mr. A. W. Bennett; the first part of this appeared in $187 \mathrm{I}$. Unfortunately neither the "Refugium" nor the "Mycological Illustrations" have ever been completed.

His entomological collection included insects of all orders, and though perhaps he gave more special attention to the Lepidoptera and Coleoptera, he was always 
anxious to get together all. the curious and striking forms he could, and his collections of Orthoptera, Hymenoptera, and Hemiptera were probably among the most extensive known.

Throughout his life he made copious notes and drawings of any natural curiosities that came under his notice, and kept a regular record of the rainfall and other meteorological occurrences. The care of all his collections, \&c., occupied so much of his time that he had little left to devote to literary work, but he always allowed free access to the collections to any who were working and might benefit from them. At Reigate he started the Reigate Natural History Club, of which he was president for many years, and which still flourishes.

He left Reigate on account of business difficulties in I873, and his collections were sold and dispersed. $\mathrm{He}$ then went to Worthing, where he resided till his death, having again surrounded himself with all the interesting plants, insects, \&c., that he could get together.

\section{TAILS $^{1}$}

II.

A NOTHER animal, the tail of which is remarkable for its mass of hairy covering, is the great ant-eater. But much more renowned is the yak, the tail of which animal is carried before dignitaries in Central Asia as an ensign of honour.

Such, then, are some of the main peculiarities of the tail in beasts. It is generally long, but may be absent altogether. It is generally hairy, sometimes very hairy, but it may be naked. It attains a prodigious size in exclusively aquatic forms, and in less aquatic forms-like the otter-it is largely developed, and somewhat flattened laterally, to aid the body in swimming.

Let us now consider the tail of a bird, and contrast it with that of a beast.

Every one knows that many birds are spoken of as having long tails, and so they have, in a sense. But a glance at the skeleton shows that it is not in the same sense that a bird and a beast are said to be "long-tailed." The bones of a bird's tail are few in number, and short, so that the tail is always very short as regards its bony portion, and also as regards the muscle and skin which covers it. At its end is a more or less conical or " ploughshare-shaped" bone, made of several vertebræ, which have coalesced together. Into the skin, which invests this shoit tail, are set the more or less long tail feathers, which form what we ordinarily call "the tail" of a bird. On the upper surface of the fleshy tail birds also carry a sort of natural pomatum-pot. It is a grease-secreting gland, especially developed in water-birds, which may constantly be observed rubbing their bills first upon this region and afterwards over the feathers of their body, in order to give them a coating of this natural unguent. It is the presence of a good supply of this coating which renders the feathers of aquatic birds so impervious to water as to cause it to be thrown off with a readiness which has given rise to the familiar saying "like water off a duck's back."

All birds without exception which now live, have but a short tail-in the true sense of the word-however long may be the feathers which clothe that tail. But it was not always so. A very ancient fossil bird has been (a few years ago) discovered in the Solenhofen slate of Germany. This fossil proves that in the secondary period, birds existed quite like our present birds in general appearance, and in the main details of their structure, but with a tail formed of a number of vertebræ of considerable length, like the tail-vertebræ of a long-tailed beast or (as we shall see) lizard. On each side of this tail were set feathers, so that altogether the structure was like nothing which is to be seen in the world about us to-day.

${ }^{x}$ A Davis lecture recently delivered at the Zoological Gardens by Prof St. George Mivart, F.R.S., V.P.Z.S. Continued from p. 512.
This bird was the renowned Archeopteryx.

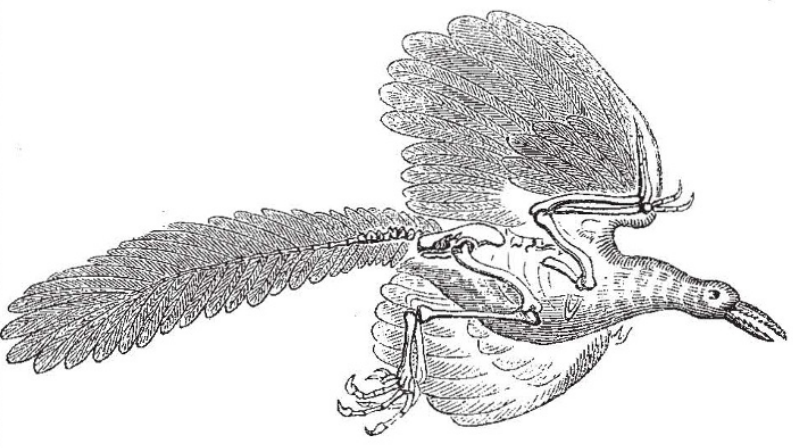

Fig. 5.-The Archeopteryx (of the Oolite strata).

But apart from such old-world wonders as this, what we call a bird's "tail" - meaning thereby the long feathers of the hinder part of its body-does not always denote really the same part.

The true "tail" of a bird (in this sense) means the collection of more or less strong and more or less elongated feathers which are implanted into the skin inresting its short bony tail.

Of this nature is the tail of an eagle, of an ostrich, and the longest of all such tails-the enormous tail of the beautiful Reeve's pheasant. You will naturally wonder why I do not include that most wonderful and magnificent object, the "tail" of a peacock. I do not include it for the simple reason that this so-called "tail" is not a tail. Not a "tail" in the sense of a beast's tail, or that of the archeopteryx; not a "tail" in the sense of anl ordinary bird's tail, i.e., it is not made of feathers implanted into the short fleshy tail.

The feathers of birds are classed by ornithologists in different groups according to their position on the body, and to each such group is given its own special name. Thus the long feathers implanted into the side of the arm and hand (by which long feathers birds fly) are called naturally "wing-feathers," but there are other feathers implanted in the body at the root of the arm, and which so lie that they cover over and protect the roots of the wing-feathers. These root, or covering, feathers, which are comparatively short feathers, are called wing-coverts. Just in the same way, there are ordinarily short feathers implanted in the hinder part of the body, which short feathers cover and protect the roots of the tail feathers. They are therefore called tail-coverts.

Now the magnificent plumes of the peacock are not tail feathers, they are tail coverts, enormously enlarged and greatly exceeding in size the true tail feathers.

You may have observed a peacock setting up its socalled tail; if not, take the next opportunity of observing it. You will see that these very long and delicate plumes are lifted up and sustained by means of certain short and stiff feathers, and if you get behind the animal, you will see these latter feathers, which can be erected and so prop up and support the great mass of long, radiating tailcoverts. These short, rigid feathers are the true tail feathers, and thus in truth the peacock has a short tail, not only as regards the skeleton, but also as regards the true tail-feathers, in spite of the length of that magnificent appendage which usage will force us still to call the peacock's "tail," even after we have made acquaintance with its real nature. Indeed it would be a piece of pedantry to call it anything else; but yet we may bear in mind, when we do call it tail, that we do not here denote by that word the same structure as we denote when we speak of the "tail" of ordinary birds.

This condition is not peculiar to the peacock, though it is the most striking instance of it. In such kinds as the grouse the tail is in large part formed by tail-coverts. 